Jurnal Konstruksi Hukum | ISSN: XXXX | E-ISSN: XXXX Vol. 1, No. 1, September 2020 Hal. 157-163| Available online at https://www.ejournal.warmadewa.ac.id/index.php/jukonhum DOI: https://doi.org/10.22225/jkh.1.1.2149.157-163

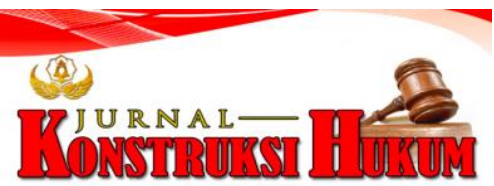

\title{
KEPEMILIKAN HAK ATAS TANAH DALAM PERKAWINAN CAMPURAN
}

\author{
I Gede Wardana Oka Sastra Wiguna, I Nyoman Putu Budiartha, I Putu Gede Seputra \\ Fakultas Hukum Universitas Warmadewa, Denpasar-Bali, Indonesia
}

\begin{abstract}
Abstrak
Kajian penelitian ini adalah tinjauan terhadap kepemilikan hak atas tanah bagi suami/istri akibat dari keberadaan perkawinan campuran, saat ini perkawinan campuran sudah ada diberbagai kalangan masyarakat Indonesia, penyebab dari peristiwa hukum ini adalah akibat dari perkembangan zaman yang serba cepat dan mudah, serta ditunjang dari pergaulan internasional yang semakin terus meningkat. Dengan banyak terjadinya perkawinan campuran di Indonesia, sudah seharusnya perlindungan hukum dalam perkawinan campuran diakomodir dengan baik dalam perundang-undangan di Indonesia. Tujuan penelitian ini yaitu memahami pengaturan kepemilikan hak atas tanah menurut Undang-undang Nomor 5 tahun 1960 tentang pokok-pokok agraria dan mengetahui status kepemilikan hak atas tanah yang dapat dimiliki dalam perkawinan campuran. Peneliti menggunakan teknik secara normatif yaitu metode penelitian hukum normatif atau metode penelitian hukum kepustakaan adalah metode atau cara yang dipergunakan di dalam penelitian hukum yang dilakukan dengan cara meneliti bahan pustaka yang ada. Penelitian ini menggambarkan bahwa kepemilikan hak atas tanah menurut Undang-undang Nomor 5 tahun 1960 tentang Peraturan Dasar Pokok Pokok Agraria secara umum hak atas tanah dapat berbentuk hak milik, hak guna usaha, hak guna bangunan dan terakhir dapat berbentuk hak pakai yang antara hak satu dengan hak yang lain memiliki pengertian berbeda dari segi batasan subyek hukum kepemilikan dan pembatasan jangka waktu kepemilikannya. Status kepemilikan hak atas tanah yang dapat dimiliki dalam perkawinan campuran adalah melekat pada orang yang memiliki kewarganegaraan Indonesia dan dalam perkawinan campuran permasalahan atas kepemilikan hak atas dapat diselesaikan dengan perjanjian perkawinan yang dibuat antara para pihak.
\end{abstract}

Kata kunci: Kepemilikan; Perkawinan campuran; Tanah

\begin{abstract}
The study of this research is a review of the ownership of land rights for husbands / wives as a result of the existence of mixed marriages, currently mixed marriages exist in various circles of Indonesian society, the cause of this legal incident is the result of the fast and easy development of the times, and is supported by international relations that continue to increase. With the occurrence of many mixed marriages in Indonesia, legal protection in mixed marriages should be accommodated properly in the legislation in Indonesia. The purpose of this research is to understand the arrangement of ownership of land rights according to Law Number 5 of 1960 concerning agrarian principles and to know the status of ownership of land rights that can be owned in mixed marriages. Researchers use normative techniques, namely normative legal research methods or library law research methods, which are methods or methods used in legal research conducted by examining existing library materials. This research illustrates that the ownership of land rights according to Law Number 5 of 1960 concerning Basic Basic Agrarian Regulations in general, land rights can be in the form of property rights, land use rights, land use rights, and finally use rights which are between one and one rights. Other rights have different meanings in terms of limitations on legal subjects of ownership and limitations on the duration of ownership. The status of ownership of land rights that can be owned in mixed marriages is attached to people who have Indonesian citizenship and in mixed marriages the problems of ownership of the rights over can be resolved by a marriage agreement made between the parties.
\end{abstract}

Keywords: Ownership; Mixed marriage; Land

\section{PENDAHULUAN}

Sebagai seorang manusia yang beragama, sudah kodratnya untuk melanjutkan keturunan sekaligus beribadah dengan cara melaksanakan perkawinan sesuai tuntunan agama (Isnaeni, 2017; Santoso, 2016). Perkawinan sendiri sudah diatur sedemikian rupa oleh Negara dalam konstitusi yang terkandung secara jelas dalam Undang- Undang Dasar 1945 serta telah diturunkan kedalam Undangundang dan peraturan pelaksananya. Perkawinan menjadi jalan utama untuk membuat dan 
menjalankan kehidupan rumah tangga (Nailaufar \& Kristiana, 2017; Saidiyah \& Julianto, 2017), yang didasarkan atas keyakinan pada nilai-nilai ketuhanan sebagaimana dimaksud dalam Pasal 1 undang-undang Nomor 1 Tahun 1974 tentang Perkawinan selanjutnya disebut undang-undang perkawinan.

Perkawinan yang dilaksanakan oleh dua orang yang memiliki kewarganegaraan yang berbeda satu dengan yang lainnya atau dalam regulasi disebut dengan perkawinan campuran seiring perkembangan jaman dan globalisasi telah sampai pada seluruh pelosok negeri bahkan terhadap daerah terpencil. Tatanan globalisasi dalam bidang informasi, ketenagakerjaan, pendidikan serta komunikasi telah menghilangkan anggapan bahwa perkawin campuran merupakan perkawinan antara orang warga negara asing yang kaya dan orang warga negara Indonesia. Perkawinan campuran juga terjadi sebagai akibat dari adanya pertukaran tenaga kerja antara negara Indonesia dengan negara sahabat (Djanggih \& Saefudin, 2019; Fauzi, 2018), hal ini menambah panjang jumkah perkawinan campuran yang terjadi di Indonesia. Perkawinan campuran sendiri pada akhirnya telah meningkat dan menjadi tren dikalangan anak bangsa. Ini disebabkan karena komunikasi dan transportasi yang setiap tahun pasti bertambah jumlahnya.

Berbagai undang-undang telah diterbitkan oleh pemerintah bersama Dewan Perwakilan Rakyat untuk menunjang problema ini, dalam hal adanya perkawinan campuran setiap warga negara yang melangsungkan perkawinan dan memiliki atau tercatat sebagai pemilik tanah berkewajiban untuk melepaskan ha katas tanahnya paling lama 1 (satu) tahun sejak perkawinan tersebut di catatkan kepada lembaga yang berhak untuk melakukan pencatatatn perkawinan. Hal yang sama berlaku bagi warga negara asing yang memiliki hak atas tanah sebagai akibat dari percampuran harta karena perkawinan tanpa adanya perjanjian kawin. Perkawinan campuran juga berpengaruh terhadap hak kewarganegaraan seseorang, apabila seorang warga negara Indonesia telah melangsungkan perkawinan dengan warga negara asing dan dalam perkawinan tersebut mewajibkan untuk melepas kewarganegaraan Indonesia maka pada saat yang sama haru hak milik atas kepemilikan atas tanah paling lama 1 (satu) tahun.

Berdasarkan latar belakang tersebut dapat dipahami, bahwa bagi setiap orang yang mulanya merupakan warga negara indonesia dan kemudian melangsungkan perkawinan dengan warga negara asing secara hukum perdata dan hukum administrasi status pertanahan terhadap seseorang tersebut dianggap sama dengan warga negara asing hal ini sebagai akibat adanya sistem percampuran harta pada peraturan perundang-undangan perkawinan yang berlaku di Indonesia dan undang-undang agrarian yang mengatur tentang pertanahan. Jika tidak dibuat demikian maka akan mucul problematika hokum tentang asas nasionalis dalam hukum pertanahan dan hukum perkawinan yang menganut sistem percampuran harta diantara suami dan istri. Adapun tujuan penelitian ini yaitu memahami pengaturan kepemilikan hak atas tanah menurut Undang-undang Nomor 5 tahun 1960 tentang Pokok-pokok Agraria dan mengetahui status kepemilikan hak atas tanah yang dapat dimiliki dalam perkawinan campuran

\section{METODE PENELITIAN}

Dalam penelitian ini menggunakan metode normatif yaitu penelitian hukum terhadap bahan pustaka maupun bahan sekunder (Mamudji, 2007). Metode penelitian hukum normatif yang digunakan dalam penulisan karya ilmiah ini menitik beratkan pada asas-asas hukum kemudian dikerelasikan pada penerapan hukumnya. Untuk memperoleh data, penulis menggunakan teknik pencatatan, penetasi, membaca buku-buku, peraturan perundang-undangan serta literatur lainnya yang ada kaitannya dengan permasalahan yang teliti. Tujuan penelitian dengan jenis penelitian normatif adalah untuk menganalisa kemudian menemukan kebenaran yang didasarkan pada logika sesuai ilmu hukum yang ada.

\section{HASIL DAN PEMBAHASAN}

\section{Pengaturan Kepemilikan Hak atas Tanah Menurut Undang-Undang Nomor 5 Tahun 1960 Tentang Pokok-Pokok Agraria}

Pengaturan mengenai tanah secara hukum perdata masuk dalam kategori benda yang tidak bergerak yang dimiliki oleh setiap orang melalui cara pendaftaran kepemilikan ha katas tanah kelembaga yang diberika otoritas untuk itu, sehingga untuk mencapai tertib hukum dalam hal kepemilikan pertanahan pemerintah berikut dengan lembaga negara membuat dan mengesahkan 
peraturan-peraturan tentang pertanahan, pengaturan undang-undang pertanahan yang dimuat dengan tidak lain memperhatikan hukum ada yang sebelumnya sudah berlaku dan diyakini oleh masyarakat Indonesia baik sistem kepemilikan maupun tentang warisan. Di Negara Republik Indonesia, berdasarkan kesepakatan antara lembaga tinggi negara telah dibuat undang-undang tentang pertanahan uang-undang yang pertama kali dibuat tahun 1960 tersebut adalah Undang-Undang Nomor 5 Tahun 1960 tentang Peraturan dasar Pokok-Pokok Agraria. Undang-Undang ini dibuat dengan memperhatikan konstitusi negara yang memberikan kekuasaan terhadap tanah, air dan angkasa yang masuk wilayah negara kesatuan negara republik merupakan dikuasai oleh negara. Tujuan paling awal dibuatnya undang-undang agrarian ini adalah untuk melindungi kepemilikan hak atas yang masuk wilayah Indonesia adalah warga negara Indonesia hal ini dalam teori hukum disebut dengan asas nasionalitas, secara definisi asas nasionalis merupakan melindungi seluruh tanah yang ada di Indonesia dari niatan warga negara asing sehingga dengan adanya peraturan yang baku dan ketat tersebut mempersempit kepemilikan hak atas tanah hanya terbatas pada Warga Negara Indonesia.

Dibuatnya aturan baku tentang batasan yang dapat dimiliki terhadap sebidang tanah oleh seseorang yang masih merupakan warga negara Indonesia menunjukan dengan jelas jelas bahwa tujuan utama pembentuk undang-undang memberikan perlindungan lebih dan memberikan perbedaan perlakuan antara warga negara Indonesia dengan warga negara asing. Peraturan yang bermuara pada perlakuan tersebut sesungguhnya masih dalam kategori wajar khususnya tentang pembahasan tanah, hal ini mengingat landasan pokok berdirinya suatu negara atau bangsa adalah kedaulatan terhadap wilayah atau tanahnya.

Dalam undang-undang pokok agraria memang mengenal namanya asas nasionalis yang membatasi kepemilikan hak atas tanah kepada warga negara Indonesia, namun pemberlakukan ini tidak berlaku mutlak artinya untuk kepemilikan hak-hak tertentu masih memungkinkan dimiliki oleh warga negara asing hal ini sejalan dengan ketentuan Pasal 9 ayat (1) Undang-Undang Pokok Agraria, pemberlakukan asas nasionalis hanya terbatas pada hak milik sebagaimana menurut Pasal 21 ayat (1), pada intinya hanya warga negara Indonesia yang memiliki hak milik (Roestamy, 2011).

Terhadap orang asing berdasarkan undang-undang agrarian yang berlaku diberikan kesempatan memiliki tanah di Indonesia dengan status Hak Pakai dan Hak Guna Bangunan, hal ini sebagaimana ketentuan dalam Pasal 30 Undang- undang Pokok Agraria pada prinsipnya menegaskan bahwa terhadap orang atau badan hukum asing hanya memiliki Hak Pakai dan Hak Guna Bangunan. Untuk kepemilikan dengan status Hak Guna Bangunan jika memperhatikan pada pasal 30 UndangUndang Nomor 5 Tahun 1960 tentang Pokok-Pokok Agrarian sesungguhnya tidak dapat dimiliki oleh orang asing, pemberian hak tersebut diberikan apabila terhadap badan hukum kepemilikan orang asing namun terdaftar sebagai badan hukum Indonesia.

Perbedaan perlakuan antara warga negara Indonesia dan warga negara asing dalam urusan pertanahan pembuat undang-undang tidak membuat dengan cara yang ekstrim, artinya dalam udang-undang pokok agrarian yang dibuat pembentuk undang-undang masih memberikan ruang kepada penanam modal asing untuk melaukan kepemilikan terhadap atas sepanjang kepemilikan tersebut sejalan dengan rencana pembangunan nasional dan kepemilikan tersebut bersifat sementara bukan bersifat permanen.

\section{Status Kepemilikan Hak atas Tanah yang dapat dimiliki dalam Perkawinan Campuran}

Melalui peraturan yang telah diterbitkan dan berlaku selama ini pemerintah tidak memberikan ruang kepada siapapun selain warga negara Indonesia yang dapat didaftarkan kepemilikannya hak atas tanahnya di tanah Indonesia, dengan ketenuan yang bersifat mutlak ini maka jelas bahwa pemerintah memberikan batasan agar dalam hal peralihan hak tidak terjadi mudah, melainkan harus menyesuaikan dengan peraturan yang ada. Ketentuan ini berarti peralihan hak atas tanah dapat dialihkan, maka pihak terhadap penerima dari hak milik tersebut tentunya harus merupakan orangorang yang memiliki hak sebagai warga negara Indonesia tunggal, atau badan-badan hukum sebagaimana dalam ketentuan Peraturan Pemerintah Nomor 38 Tahun 1963 tentang penunjukan Badan-Badan Hukum Yang Dapat Mempunyai Hak Milik Atas Tanah (Roestamy, 2011).

Status kepemilikan hak atas tanah secara hukum mengandung arti bahwa kepemiliki tersebut merupakan tanda bukti yang terkuat dan terpenuh, namun kendati dalam kepemilikan berdasarkan hak 
milik mengandung arti terkuat dan terpenuh bukan berarti kepemilikan tersbebut bersifat mutlak, dak dapat diganggu-gugat, tak terbatas. Unsur terkuat dan terpenuh tersebut memiliki tujuan untuk membedakannya kekuatan hukum dengan hak guna usaha, hak guna bangunan, hak pakai, maupun hak lainnya. Perbedaan yang dimuat adalah ketika terjadi permasalahan diantara hak-hak tersebut maka secara hukum Indonesia hak miliklah yang mempunyai kekuatan hukum paling kuat dan paling penuh. Pasal 21 ayat (4) Undang-Undang Pokok Agraria menyatakan bahwa seseorang yang mempunyai dua kewarganegaraan walaupun yang salah satu kewarganegaraan tersebut merupakan warga negara Indonesia secara undang-undang agraria tetap disebut sebagai orang asing. Peristiwa hukum yang menyebabkan beralihnya hak Milik kepada pihak-pihak tidak berwenang sebagai pemegang Hak Milik seperti warga negara asing, masih diakui/diperbolehkan oleh Undang-Undang Pokok Agraria dengan syarat orang asing tersebut tidak boleh memegang Hak Milik itu lebih dari satu tahun dan harus mengalihkannya kepada pihak yang memenuhi syarat.

Berdasarkan hal-hal tersebut dapat disimpulkan bahwa hak milik merupakan hak terkuat atas suatu tanah, dalam arti hak ini bersifat mutlak dan tidak dapat diganggu gugat oleh pihak lainnya, hak milik memiliki karakter berbeda dari hak-hak yang lainnya, perbedaan dimaksud dalam hak milik melekat asas nasionalis yang berarti hanya seseorang yang memiliki kewarganegaraan Indonesia yang dapat memiliki atau dicatatkan namanya pada pendaftaran hak milik dan pada hak milik merupakan pemberian hak yang bersifat tetap.

Perbedaan dengan hak lain misalnya dengan hak guna bangunan dan hak guna usaha yang memiliki karakteristik bersifat sementara dan berbatas waktu serta dapat didaftarkan oleh subyek hukum badan hukum yang terdaftar di Indonesia. Perbedaan juga dimiliki pada Pemberian hak pakai yang memiliki karakteristik tidak melekat pada asas nasionalis sehingga penguasaan pada hak pakai dapat dimiliki oleh orang yang bukan warga negara Indonesia, namun harus memenuhi sesuai ketentuan peraturan agrarian di Indonesia. Perkawinan campuran apabila ditinjau dari undang-undang perkawinan yang berlaku di Indonesia yaitu perkawinan antara warga negara indonesia dengan warga negara asing yang dilangsungkan di Indonesia. Secara aturan hukum suami isteri dalam perkawinan campuran harus bersesuaian dengan ketnetuan hukum perkawinan yang berlaku di Indonesia, yaitu UndangUndang Nomor 1 Tahun 1974 tentang Perkawinan. Pengertian kedudukan suami-isteri dalam Udangundang Nomor 1 Tahun 1974 tentang Perkawinan mengandung arti bahwa terdapat ketentuan tentang hak dan kewajiban sebagai sepasang suami-isteri baik terhadap harta yang diperoleh dalam perkawinan, harta bawaan atau hak dan kewajiban lainnya. Lebih detail hak dan kewajiban untuk warga negara yang melangsungkan perkawinan campuran akan diatus dalam Undang-Undang Nomor 1 Tahun 1974 tentang Perkawinan. Perkawinan campuran merupakan perkawinan antara warga negara.

Indonesia dengan warga negara asing yang dilangsungkan di Indonesia. Akibat dilakukannya perkawinan tidak melihat apakah antara pasangan suami istri warga negara Indonesia atau warga negara asing, setiap perkawinan yang tunduk pada undang-undang perkawinan berimplikasi pada harta benda maupun hutang selama perkawinan. Bedasarkan Undang-Undang Nomor 1 Tahun 1974 tentang Perkawinan Pasal 59 ayat (2) pada intinya menjelaskan bahwa setiap Perkawinan campuran yang dilangsungkan di Indonesia wajib dilakukan berdasarkan ketentuan-ketentuan yang diatur dalam undang-undang perkawinan.

Pengaturan terhadap harta benda dalam perkawinan telah diatur dalam Pasal 35 sampai dengan pasal 37 Undang-undang Nomor 1 Tahun 1974 tentang Perkawinan. Dalam perkawinan campuran sebagaimana Pasal 35 menjelaskan bahwa hsegala harta yang diperoleh selama masa perkawinan berlangsung menjadi harta bersama atau harta dimiliki secara bersama-sama secara proporsional, terhadap harta yang diperoleh dan dibawa sebelum masa perkawinan disebut dengan harta bawaan, menjadi hak milik masing-masing pihak sepanjang para pihak sepakat untuk tidak mengikatnya menjadi harta bersama. Ketentuan lebih lanjut dalam Pasal 36 pada intinya menegaskan bahwa segala pembahasan atau peralihan harta bersama dapat dilakukan oleh suami atau isteri sepanjang mendapat persetujuan dari kedua belah pihak dan untuk harta yang berstatus harta bawaan segala pembahasan atau peralihan dapat dilakukan sepihak baik oleh suami atau istri yang berhak terhadap harta tersebut. Apabila ditelaah lebih detail hal-hal yang dimuat dalam ketentuan Pasal 35, Pasal 36 dan Pasal 37 Undang-undang Nomor 1 Tahun 1974 tentang perkawinan telah sejalan dan diambil dari ketentuan hukum adat yang berlaku di Indonesia (Manan, 2006). Ketika 
pengertian dan pembahasan ditelisik dari pengertian secara umum yaitu dari pengertian dalam Kamus Besar Bahasa Indonesia setiap harta benda yang masuk dalam kategori harta bersama adalah harta yang diperoleh suami selama perkawinan berlangsung. Untuk harta bawaan kamus besar Bahasa Indonesia memberikan pengertian bahwa harta tersebut merupakan harta yang dibawa pada saat dan/atau perkawinan (Nasional, 2007).

Harta bersama dalam ilmu hukum diartikan bahwa keseluruhan harta yang ada pada saat perkawinan sedang berlangsung tanpa melihat sumber harta tersebut apakah dari penghasilan pihak suami ataupun penghasilan dari pihak istri dan tidak membatasi pada atas nama yang didaftarkan dalam harta besama tersebut. Yang menjadi harta masing-masing pihak yang terkait dalam perkawinan diantaranya (Manan, 2006).

a. Harta bawaan merupakan harta yang telah ada sebelum perkawinan berlangsung.

b. Harta yang ada pada saat perkawinan namun terhadap sumber harta tersebut merupakan pemberian hadiah, pemberian hibah, dan/atau warisan dari masing-masing pihak dalam perkawinan.

Apabila terkait dengan harta bersama ini ditinjau dari sisi hukum adat terdapat pandangan ahli yang menyatakan bahwa segala harta yang ada dan diperoleh selama perkawinan berlangsung merupakan harta pencarian bersama sehingga terhadap harta tersebut menjadi harta bersama yang biasanya disebut harta syarikat (Harahap, 1997). Keberadaan harta bersama dalam perkawinan sesungguhnya ditentukan masa/jangka waktu perkawinan antara suami isteri, dengan dilangsungkannya perkawinannya antara suami dan istri, berarti selama perkawinan berlangsung terhadap harta yang dihasilkan semasih perkawinan berlangsung merupakan. Hal ini dikecualikan terhadap harta yang bersumber dari hadiah, hibah dan warisan yang dimiliki oleh salah satu pihak walaupun diperoleh semasa perkawinan berlangsung. Mengenai kepemilikan tanah terhadap warga negara Indonesia yang menjadi harta bersama akibat berlangsungnya perkawinan campuran, kendatipun dalam setiap perkawinan termasuk perkawinan campuran terjadi percampuan harta menjadi milik harta bersama diantara suami dan istri, suami atau istri yang masih terdaftar sebagai warga negara Indonesia sesuai asas nasionalis tetap menjadi kepemilikan suami atau isteri yang masih menjadi warga negara Indonesia tersebut. Hal ini tidak berlaku untuk suami atau istri yang berwarga negara asing, sesuai dengan peraturan agrarian terhadap suami atau isteri yang berkewarganegaraan asing tersebut kepemilikan atas haknya terbatas hanya berhak dengan status hak pakai. Penguasaan hak terhadap tanah yang menjadi obyek tersebut sesungguhnya tetap menjadi milik bersama namun dikarenakan adanya unsur orang asing makan status tanah tersebut berubah tidak lagi sebagai hak milik. Dalam rangka mengatasi kekakuan hukum yang cenderung menyulitkan masyarakat, pihak-pihak yang merasa dirugikan akan aturan ini kemudian mengajukan uji materiil ke Makhmakah Kosntitusi, Mahkamah Konstitusi berdasarkan kewenangannya telah mengeluarkan Putusan terhadap perkara ini dengan Putusan Nomor 69/PUU-XIII/2015, sebelum dilkeluarkannya putusan ini peraturan perundang-undangan telah mengetua tentang perjanjian perkawinan pad aintinya menyatakan adalah perjanjian perkawinan dilaksanakan seharusnya dilaksanakan sebelum perkawinan berlangsung, perjanjian ini dibuat secara tertulis atas kesepakatan masing-masing mempelai, isi perjanjian merupakan juga mengikat kepada pihak ketiga yang terlibat dalam perjanjian perkawinan yang dibuat dan terhadap perjanjian bersama tersebut disahkan dan dicatatkan pada instansi yagn berwenang dalam perkawinan. Masa berlaku perjanjian perkawinan adalah sejak perkawinan diantara kedua mempelai dilangsungkan, batasan terhadap perjanjian ini adalah selama perkawinan berlangsung para pihak tidak dapat mengubah perjanjian perkawinan kecuali terhadap kesepakatan untuk melakukan perubahan dan terhadap perubahan tersebut tidak ada unsur merugikan pihak ketiga.

Peraturan tentang perjanjian perkawinan Berdasarkan undang-undang di atas, bahwa perjanjian perkawinan hanya dapadalam undang-undang perkawinan memberikan pengertian bahwa perjanjian perkawinan hanya dapat dibuat sebelum perkawinan berlangsung, makna tersebut menutup ruang bagi pasangan yang akan melangsungkan perkawinan pada saat perkawinan sedang berlangsung dan telah memenuhi kesepakatan diantara kedua mempelai. Sejak perkara ini digulirkan dan diajukan kepada Mahkamah Konstitusi terjadi pro dan kontra dimasyarakat, kemudian dalam keputusannya Mahkamah Kosntitusi telah memutuskan melalui putusan Mahkamah Konstitusi Nomor 69/PUU-XIII/2015, tertanggal tanggal 21 Maret 2015, dalam putusan Mahkamah Kosntitusi 
tersebut pada prinsipnya telah mengabulkan uji materiil pemohon dan mengubah paradigm perjanjian perkawinan yang berlangsung selama ini, perubahan tersebut diantaranya menghapuskan batasan terhadap pembuatan perjanjian perkawinan yang hanya dapat dilaksanakan sebelum perkawinan oleh mahkamah dihapuskan sehingga masyarakat tidak lagi terbelenggu atas kebebasan dalam berkontrak ini. Mahkamah konstitusi memandang bahwa perjanjian perkawinan merupakan perjanjian yang rohnya merupakan perjanjian yang dimaksud dalam hukum perdata, dimana dalam perjanjian terkadung asas kebebasan berkontrak, sehingga pembatasan berkontrak yang ada dalam undangundang perkawinan selama ini dan cenderung merugikan masyarakat dalam lapangan hukum keperdataan sudah sepatutnya dilakukan perubahan, sehingga sejak keputusan ini dikeluarkan mahkamah memperluas pembuatan perjanjian perkawinan bukan hanya sebelum perkawinan akan tetapi dapat dibuat selama perkawinan berlangsung. Penulis dapat menyimpulkan terhadap perkawinan campuran antara warga negara Indonesia dengan warga negara asing ketika dikorelasikan dengan hukum pertanahan tentu menimbulkan konsekuensi hukum, dalam hukum pertanahan Indonesia sendiri menganut asas nasionalis yang menutup ruang kepada pihak warga negara asing untuk mendaftarkan haknya, permasalahan mengenai percampuran harta dalam hukum perkawinan pasca dikeluarkannya Putusan Mahkamah Konstitusi tentang perjanjian perkawinan, sehingga perjanjian perkawinan yang tidak terbatas pada waktu dapat memberikan ruang kepada warga negara Indonesia untuk membuat kesepakatan tentang harta- harta yang diperoleh selama perkawinan.

\section{SIMPULAN DAN SARAN}

\section{Simpulan}

Kepemilikan hak atas tanah menurut undang-undang nomor 5 tahun 1960 tentang Pokokpokok Agraria secara umum hanya warga negara Indonesia yang bisa mendapatkan hak milik, sedangkan warga negara asing hanya bisa mendapatkan hak guna usaha, hak guna bangunan dan terakhir dapat berbentuk hak pakai yang antara hak satu dengan hak yang lain memiliki karakteristik berbeda dari segi batasan subyek hukum kepemilikan dan pembatasan jangka waktu kepemilikan haknya dan Status kepemilikan hak atas tanah yang dapat dimiliki dalam perkawinan campuran adalah melekat pada orang yang memiliki kewarganegaraan Indonesia dan dalam perkawinan campuran permasalahan atas kepemilikan hak atas dalam dapat disesuikan dengan perjanjian perkawinan yang dibuat antara para pihak.

\section{Saran}

Untuk menciptakan keadilan dimasyarakat pada era globalisasi dan perkembangan jaman yang cenderung cepat, tentunya penyempurnaan terhadap peraturan perundang-undangan wajib dilakukan, fenomena perkawinan campuran bukan hal yang aneh saat ini, sehingga pemahaman dan transparansi pihak yang terlibat dalam proses pendaftaran tanah, agar tercipta perlindungan terhadap seluruh masyrakat dan mengurangi sengketa dalam bidang pertanahan.

\section{DAFTAR PUSTAKA}

Djanggih, H., \& Saefudin, Y. (2019). Problematika Status Kewarganegaraan Anak Melampaui Batas Usia 21 Tahun: Studi Kasus Provinsi Bali. Jurnal Penelitian Hukum, 19(7), 413-425.

Fauzi, R. (2018). Perkawinan Campuran Dan Dampak Terhadap Kewarganegaraan Dan Status Anak Menurut Undang-Undang Di Indonesia. Soumatera Law Review, 1(1), 153.

Harahap, M. Y. (1997). Kedudukan Kewenangan dan Acara Peradilan Agama UU No.7 Tahun 1989. Pustaka Kartini.

Isnaeni, M. (2017). Palu Godam Hakim Mahkamah Konstitusi Menafikan Hakekat Perjanjian Perkawinan. Fakultas Hukum Universitas.

Mamudji, S. S. dan S. (2007). Penelitian hukum normatif: suatu tinjauan singkat. Raja Grafindo Persada

Manan, A. (2006). Aneka Masalah Hukum Perdata Islam di Indonesia, Ed. I, Cet. I. Kencana Prenada Media Group.

Nailaufar, U., \& Kristiana, I. F. (2017). Pengalaman Menjalani Kehidupan Berkeluarga Bagi Individu Yang Menikah Di Usia Remaja. Empati: Jurnal Karya Ilmiah S1 Undip, 6(3), 233-244.

Nasional, P. B. D. P. (2007). Kamus Besar Bahasa Indonesia Ed. III, Cet. IV. Balai Pustaka.

Roestamy, M. (2011). Konsep-konsep Hukum Kepemilikan Properti bagi asing dihubungkan dengan 
Hukum Pertanahan. Alumni, Bandung.

Saidiyah, S., \& Julianto, V. (2017). Problem Pernikahan dan Strategi Penyelesaiannya: Studi Kasus pada Pasangan Suami Istri dengan Usia Perkawinan di Bawah Sepuluh Tahun. Jurnal Psikologi Undip, 15(2), 124.

Santoso. (2016). Hakekat Perkawinan Menurut Undang-Undang Perkawinan, Hukum Islam dan Hukum Adat. Yudisia, 7(2), 412-434. 